GENOME METHODS

\title{
Use of a Fluorescent-PCR Reaction to Detect Genomic Sequence Copy Number and Transcriptional Abundance
}

\author{
Pei-Wen Chiang, ${ }^{1,7,8}$ Woo-Joo Song, ${ }^{2,7}$ Kai-Yuan Wu, ${ }^{3}$ \\ Julie R. Korenberg, ${ }^{4}$ Eric J. Fogel, ${ }^{1}$ Margaret L. Van Keuren, ${ }^{2}$ \\ Deval Lashkari, ${ }^{5}$ and David M. Kurnit ${ }^{1,2,6}$
}

\author{
${ }^{1}$ Departments of Pediatrics and ${ }^{6}$ Human Genetics, ${ }^{2}$ Howard Hughes Medical Institute, University of \\ Michigan Medical School, Ann Arbor, Michigan 48109-0650; ${ }^{3}$ Biotronics Corporation, Lowell, \\ Massachusetts 01851; ${ }^{4}$ Department of Medical Genetics, Cedars-Sinai Medical Center, Los Angeles, \\ California 90048-1869; ${ }^{5}$ Stanford DNA Sequence and Technology Center, Departments of Genetics and \\ Biochemistry, Stanford University School of Medicine, Stanford, California 94305
}

We present a fluorescent-PCR-based technique to assay genomic sequence copy number and transcriptional abundance. This technique relies on the ability to follow fluorescent PCR progressively in real time during the exponential phase of the reaction so that quantitative PCR is accomplished. We demonstrated the ability of this technique to quantitate both known deletions and amplifications of loci that have been measured previously by other methods, and to measure transcriptional abundance. Using an efficient variant of the fluorescent-PCR technology, we can monitor transcription semiquantitatively. The ability to detect all amplifications and deletions at any single copy locus by PCR makes this the technique of choice to assay genomic sequence copy number anomalies in birth defects and cancers. The ability to detect variations in transcript abundance enables this technique to fashion a time and tissue analysis of transcription.

Traditional PCR, assayed by monitoring PCR products run on a gel, is not quantitative, as it does not reflect the initial substrate concentration. To circumvent this limitation, we describe a fluorescent-PCR assay that is followed during the exponential phase of the PCR reaction, permitting quantitation. This reaction can be made fully quantitative by comparing three control reactions and an unknown, or semiquantitiative by comparing the unknown against one standard. We illustrate the use of the fully quantitative reaction to monitor genome copy number alterations involved in birth defects and cancer. We illustrate the use of the semiquantitative reaction to monitor abundance of transcripts in numerous cDNA libraries.

Genome instability, defined to include amplification or deletion of part of the genome,

\footnotetext{
${ }^{7}$ These authors contributed equally to this work. ${ }^{8}$ Corresponding author.
} E-MAIL pwchiang@umich.edu; FAX (313) 936-9353. underlies a variety of human disorders. In dysmorphology, trisomy or monosomy for parts of the genome are associated with clinical syndromes, for example, Down syndrome (Scoggin and Patterson 1982), DiGeorge syndrome (DGS; Driscoll et al. 1992), Charcot-Marie-Tooth disease type 1A (CMT1A, a result of three copies of the PMP22 gene), and its complement, hereditary neuropathy with liability to pressure palsies (HNPP, a result of one copy of the PMP22 gene; Dyck et al. 1993). In cancer, amplification of oncogenes (e.g., HER2/neu; Slamon et al. 1989) or deletion of tumor suppressor genes (e.g., p53; Nigro et al. 1989) are found frequently in tumors. Currently, detection of such genome instability is accomplished via two different groups of methods. The methods of the first group, which only detect monosomy of a given sequence in informative cases, rely on informative sequence variations [different restriction enzyme cutting sites for restriction fragment length polymorphisms (RFLPs; Botstein et al. 1980) or different size of 
PCR products for loss of heterozygosity analysis (LOH; Lasko et al. 1991)] between two alleles in the genome. The methods of the second group, which are considerably more laborious but can detect both deletions and amplifications, rely on either quantitative Southern blotting (1975) or fluorescent in situ hybridization (FISH) (Van Ommen et al. 1995). Both RFLP and PCR analyses of $\mathrm{LOH}$ are restricted by the need for polymorphic markers, which may be uninformative in a given case, and are often at some distance from the locus of interest. Quantitative Southern blotting and FISH can detect either gain or loss of sequences without the heterozygosity requirements of the RFLP or PCR-polymorphism methods; however, these quantitative Southern blot or FISH methods are difficult to perform, are timeconsuming, use large amounts of material or specialized tissue samples, and may offer limited resolution.

These difficulties point to the use of quantitative PCR (Mansfield 1993; Von Eggeling et al. 1993; Inoue et al. 1996) as an ideal solution to the above conundra. However, the quantitative PCR methods described to date can only quantitate samples at a fixed reaction end-point (usually after the completion of PCR). Assays relying on such fixed end-point analyses cannot utilize the exponential phase of the reaction and thus require competitive PCR technologies for quantitation or require that the reaction be in late exponential phase to accumulate detectable substrate. Therefore, these methods are inherently not accurate or rapid enough to detect small changes in copy number reproducibly. We describe below a quantitative fluorescent-PCR assay that can be observed dynamically in exponential phase and, thereby, allows accurate measurements of copy number.

Although the fluorescent-PCR assay also can be used to pinpoint the abundance of a transcript in cDNA libraries, a less stringent version of the fluorescent-PCR method can accomplish the semiquantitative screening of cDNA libraries. Comparison of the fluorescent-PCR screen with gel-based PCR screens shows this technique to be both sensitive and accurate. Because no postamplification electrophoresis on gels is required, the method can be automated. With exponential growth of the number of genes discovered as the genomic initiative proceeds, automation of the fluorescent-PCR method will permit a rapid and sensitive time and tissue analysis of genic transcription.

\section{RESULTS}

\section{Analysis of Aneusomy for Chromosome 21 Using Fluorescent-PCR}

The strategy of our assay is similar to that used by previous authors (Von Eggeling et al. 1993). Two PCR reactions were performed in parallel on both the unknown and the reference samples. In Table 1 , primers from the experimental $S 100 \beta$ marker on chromosome 21 were used for one PCR reaction and compared with the PCR reaction achieved with primers from the reference (eusomic) IGF-1 marker on chromosome 12. Because both reactions were monitored in exponential phase, the PCR signal depended directly on the initial target concentration. Under these conditions, the ratio of PCR signal from the two reactions $(S 100 \beta / I G F-1)$ in the unknown DNA, divided by the ratio of PCR signal from the two reactions $(S 100 \beta / I G F-1)$ in the control (normal placental) DNA, accurately reflected the relative dosage of $S 100 \beta$ to IGF-1 in the unknown DNA. Because the dosage of IGF-1 in both cell lines (two copies/genome) and of $S 100 \beta$ in the control cell line (two copies/genome) is known, the dos-

\begin{tabular}{|c|c|c|c|}
\hline & $\begin{array}{l}\text { Ratio of } \\
\text { gene } \\
\text { copy no. } \\
\text { (target/ } \\
\text { reference) }\end{array}$ & $\begin{array}{l}\text { Standard } \\
\text { deviation }\end{array}$ & $\begin{array}{l}\text { Sample } \\
\text { no. }\end{array}$ \\
\hline Del21ILS & 0.50 & 0.10 & 12 \\
\hline Dup21WB & 1.61 & 0.26 & 10 \\
\hline Dup21NA & 1.11 & 0.14 & 10 \\
\hline Dup21DS & 1.65 & 0.17 & 10 \\
\hline Del6918 & 1.18 & 0.12 & 12 \\
\hline \multicolumn{4}{|c|}{ 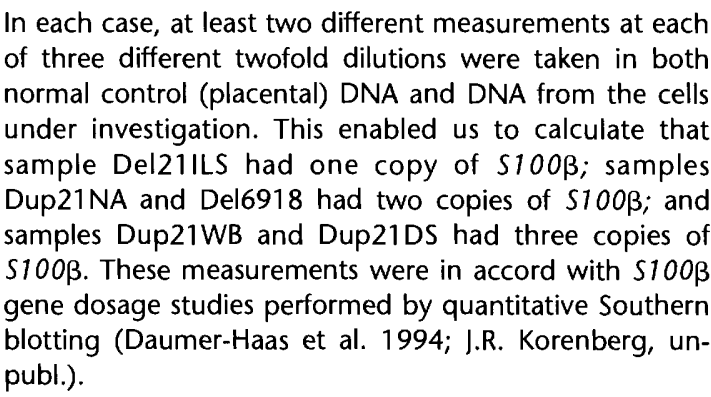 } \\
\hline
\end{tabular}




\section{FLUORESCENT-PCR REACIION}

age of $S 100 \beta$ in the experimental cell line can be determined.

To evaluate the fluorescent-PCR method for detecting genome instability, we selected five different samples with segmental aneusomy for chromosome 21 analyzed by quantitative Southern blotting previously (J.R. Korenberg, unpubl.). The copy numbers of the $S 100 \beta$ marker on chromosome 21 derived in a blinded fashion were three for samples Dup21WB and Dup21DS, two for samples Dup21NA and Del6918 and one for sample Del21ILS (Table 1). In each case, these copy numbers matched the previous results measured by quantitative Southern blotting (J.R. Korenberg, unpubl.). Therefore, the AmpliSensor method accurately detected the $S 100 \beta$ copy numbers from five different samples with segmental aneusomy for chromosome 21 , including samples both trisomic and monosomic at this locus.

\section{The AmpliSensor Method Successfully Detected Both Gene Deletions and Amplifications in Two Different Tumor Cell Lines}

To further evaluate the AmpliSensor method, genomic DNAs from two breast tumor cell lines, MCF-7 and T-47D, were analyzed by this method. The T-47D cell line has only one defective copy of p53 (Nigro et al. 1989) and the MCF-7 cell line has only one copy of $e r b B-2$ (Casey et al. 1991). Both the $p 53$ and erbB-2 markers are on chromosome 17; the $S 100 \beta$ marker on chromosome 21 was used as the reference marker. As shown in Figure $1 \mathrm{~A}$ ( $p 53$ in T-47D cells) and Figure 1B (erbB-2 in MCF-7 cells), the normalized quantitative curves (detection index of $p 53$ in T-47D DNA or erbB-2 in MCF-7 DNA) are both less than that of placenta DNA, demonstrating deletions of these genes in these cell lines. Therefore, the AmpliSensor method successfully detected known gene deletions that were seen previously using other technologies.

An advantage of the AmpliSensor method is that it becomes possible to analyze gene copy number along a chromosome by scanning copy number for markers along that chromosome. Having successfully applied the AmpliSensor method for the detection of known DNA sequence deletions from two tumor cell lines, we elected to scan multiple markers on chromosome 17 from the MCF-7 cell line. MCF-7 genomic DNA was analyzed by scanning four markers on chromosome 17 (p53 (17p13), SUPT6H (17q11.2), BRCA1 (17q21) and SUPT4H (17q21q23); SUPT6H and SUPT4H are two human genes we isolated on chromosome 17 related to the yeast global transcription regulators, SPT6 and SPT4 (Chiang et al. 1996a,b). As shown in Figures 1C-F, the p53 marker is deleted (Fig. 1C), the SUPT6H marker exhibits normal copy number (Fig. 1D), and the SUPT4H (Fig. 1E) and BRCA1 (Fig. 1F) markers are amplified in MCF-7 cells. Because the normalized quantitative curve does not accurately yield the copy number difference, this quantitative analysis was further analyzed using the ASAP software (see Methods). As shown in Table 2 , the copy number (relative gene dosage) of $p 53$ in MCF-7 cells is about half of that of the placental DNA control (0.43); the copy number of SUPT6H is about the same as that from placenta control (1.08); and the copy numbers of both BRCA1 and SUPT4H are about threefold that of the placenta control (3.06-fold for BRCA1, and 2.97-fold for SUPT4H). The data thus demonstrate deletion, a normal level, and amplification of copy number for different loci on chromosome 17 in MCF-7 genomic DNA.

\section{Analyses of Gene Transcription Using the Fluorescent-PCR Assay}

The assay can be used in an analogous manner to determine the abundance of a sequence in cDNA libraries. We took advantage of the fact that the primers we had for BRCA1 could be used for both genomic and genic DNA samples, as they did not cross an intron. Using a fluorescent marker for glucose 3-phosphate dehydrogenase (G3PDH), a ubiquitously transcribed, moderately abundant sequence, we could derive the ratio between $B R C A 1$ and $G 3 P D H$ and, thereby, determine the relative abundance between $B R C A 1$ and G3PDH transcription. There was no significant variation for the ratio between $B R C A 1$ and G3PDH in the 11 tissues we examined (Table 3 ), demonstrating that $B R C A 1$ is transcribed ubiquitously in these tissues at a rate equal to $\sim 1 / 2000$ of that of the moderately abundant G3PDH transcript.

\section{Semiquantitative Analysis Using the Fluorescent-PCR Protocol}

We next investigated the suitability of the fluorescent-PCR assay to monitor transcription using 


\section{CHIANG ET AL.}
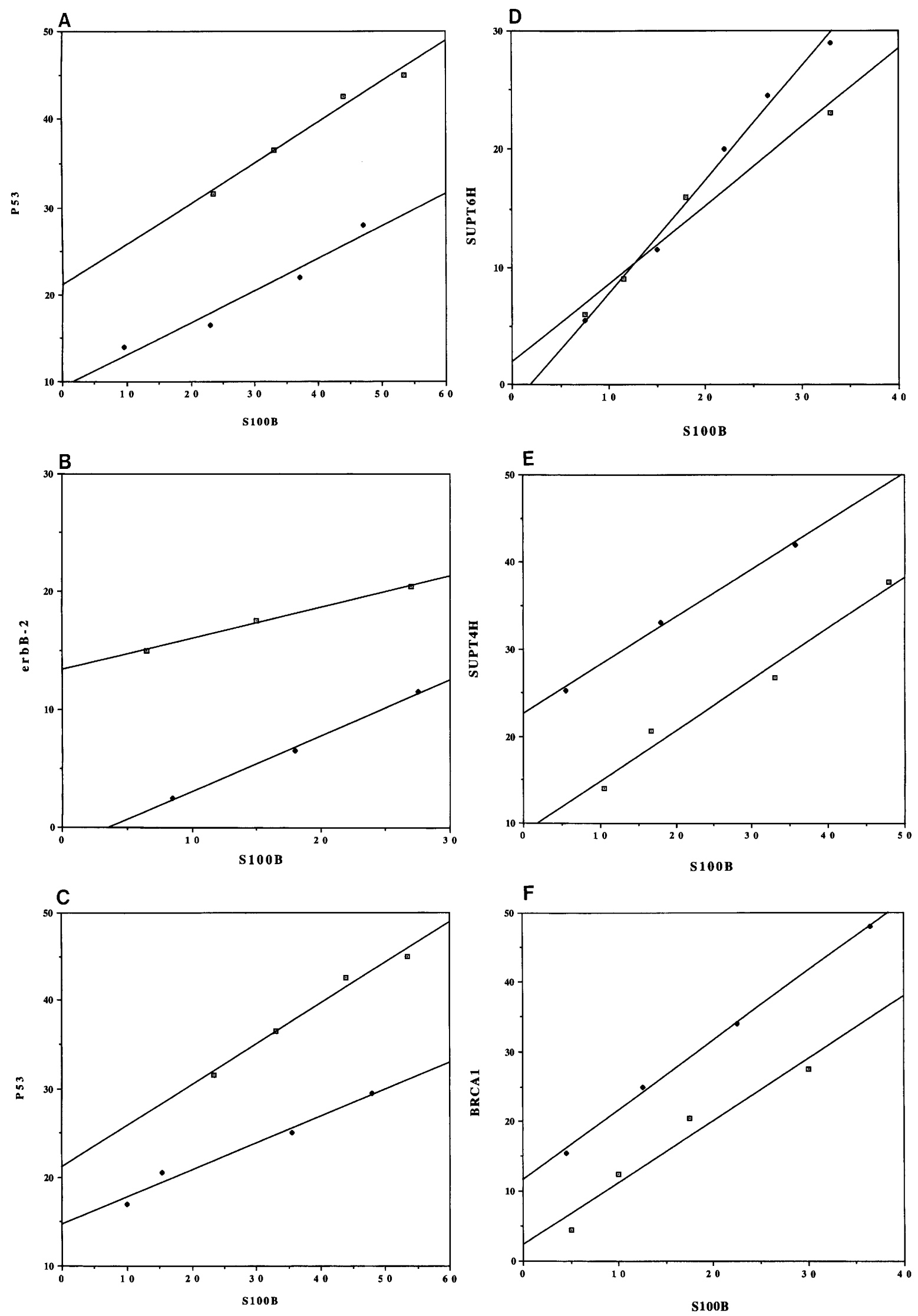

Figure 1 (See facing page for legend.) 
FLUORESCENT-PCR REACTION

\begin{tabular}{|c|c|c|c|}
\hline & $\begin{array}{l}\text { Ratio of gene } \\
\text { copy no. } \\
\text { (target/ } \\
\text { reference) }\end{array}$ & $\begin{array}{l}\text { Standard } \\
\text { deviation }\end{array}$ & $\begin{array}{l}\text { Sample } \\
\text { no. }\end{array}$ \\
\hline BRCA1 & 3.06 & 0.12 & 8 \\
\hline SUPT4H & 2.97 & 0.13 & 6 \\
\hline p53 & 0.43 & 0.13 & 8 \\
\hline SUPT6H & 1.08 & 0.03 & 8 \\
\hline \multicolumn{4}{|c|}{$\begin{array}{l}\text { Copy number was calculated by use of placental DNA as } \\
\text { an internal reference with the known } 5100 \beta \text { marker on } \\
\text { chromosome } 21 \text { (two copies in both placental DNA and in } \\
\text { MCF-7 genomic DNA) and the unknown markers on chro- } \\
\text { mosome } 17 \text { (two copies in placental DNA and an un- } \\
\text { known quantity in MCF-7 genomic DNA). At least three } \\
\text { different dilutions of each sample with a twofold differ- } \\
\text { ence of each dilution were analyzed. Each dilution was } \\
\text { duplicated in the analysis. The results for MCF-7 cells show } \\
\text { that SUPT } 6 H \text { is present in approximately normal copy } \\
\text { number (two copies/genome), p53 dosage is approxi- } \\
\text { mately half of normal copy number (one copy/genome), } \\
\text { and SUPT } 4 H \text { and BRCA1 are present in approximately three } \\
\text { times normal copy number (six copies/genome). }\end{array}$} \\
\hline
\end{tabular}

several control genes. For this assay, one of the gene-specific primers is attached to the F (fluoroscein isothiocyanate carrying)-strand for sequence-specific amplification. This was accomplished by synthesizing (Lashkari et al. 1995) a primer carrying the 7-bp "hook" sequence [5'GGGACGC-3', complementary to the 7-bp single-stranded overhang generated by annealing F- and $\mathrm{T}$ (Texas Red carrying)-strands] followed by the usual PCR primer sequence that remains single-stranded. Following annealing and ligation, PCR was then performed between the single-stranded part of this partially duplex primer and the other specific primer. As noted above, successful PCR results in separation of the two strands of the oligonucleotide duplex; the resulting separation of $\mathrm{F}$ and $\mathrm{T}$ yields a decrement

\begin{tabular}{|c|c|c|c|}
\hline \multirow[b]{2}{*}{ cDNA library } & \multicolumn{2}{|c|}{ Quantity } & \multirow{2}{*}{$\begin{array}{l}\text { BRCA1/ } \\
\text { G3PDH } \\
\left(\times 10^{-3}\right)\end{array}$} \\
\hline & G3PDH & $B R C A 1$ & \\
\hline Kidney & 4130 & 8.43 & 2.04 \\
\hline Liver & 6980 & 8.19 & 1.17 \\
\hline Lung & 5460 & 9.92 & 1.82 \\
\hline Heart & 11500 & 20.10 & 1.75 \\
\hline Brain & 3520 & 8.58 & 2.44 \\
\hline Leukocyte & 3080 & 9.76 & 3.17 \\
\hline Fetal kidney & 3580 & 7.46 & 2.08 \\
\hline Fetal liver & 6330 & 22.30 & 3.52 \\
\hline Fetal lung & 4440 & 10.90 & 2.45 \\
\hline Fetal heart & 14540 & 18.70 & 1.29 \\
\hline Fetal brain & 3430 & 10.60 & 3.09 \\
\hline Heart & 9210 & 20.90 & 2.27 \\
\hline
\end{tabular}

Relative abundance between the $B R C A 1$ and $G 3 P D H$ genes was calculated in 11 different CDNA libraries. G3PDH is an abundant gene that is transcribed constitutively in all tissues. The ratio, BRCA1/G3PDH, yields the relative abundance between these two genes. The average for the 11 CDNA libraries is a ratio between $B R C A 1$ and G3PDH transcription $=2.3 \times 10^{-3}$. in energy transfer (Fig. 2). This generic primer is approximately fivefold less sensitive than AmpliSensors tailored for specific genes; this decrease in sensitivity renders this application semiquantitative, which is still sufficient for sampling tissues for transcript abundance within an order of magnitude.

Multiple variables were optimized, including protocols to (1) purify primers; (2) kinase and ligate primer oligonucleotide sequences; (3) make buffers; (4) use primer concentrations, and (5) determine PCR cycle numbers. We found that a preamplification step of 30 cycles with a genespecific nonfluorescent primer and an anchored primer was needed before a second amplification step utilizing a second (nested) gene-specific primer attached to the fluorescent oligonucleo-

Figure 1 Quantitative analysis of genomic DNA by different markers on chromosome 17. The normalized quantitative curves were derived by plotting the detection index obtained from the chromosome 17 marker (ordinate) against that from $S 100 \beta$ (abscissa). (R) regression coefficient; (n) sample number. (A) ( $\square$ ) Placenta control; $\mathrm{R}=0.981 ; \mathrm{n}=8$; ( ) T-47D; $\mathrm{R}=0.950 ; \mathrm{n}=8$. (B) ( $\square$ ) Placenta control; $\mathrm{R}=0.998 ; \mathrm{n}=6$; ( $)$ MCF-7; $\mathrm{R}=0.996 ; \mathrm{n}=6$. (C) ( $\square)$ Placenta control; $\mathrm{R}=0.981 ; \mathrm{n}=8 ;(\diamond) \mathrm{MCF}-7 ; \mathrm{R}=0.977 ; \mathrm{n}=8$. (D) ( $\square) \mathrm{MCF}-7$; $\mathrm{R}=0.963 ; \mathrm{n}=8 ;(\diamond)$ Placenta control; $\mathrm{R}=0.991 ; \mathrm{n}=8$. (E) ( $\square)$ Placenta control; $\mathrm{R}=0.974 ; \mathrm{n}=8 ;(\diamond)$ MCF-7; $\mathrm{R}=0.997 ; \mathrm{n}=6 .(f)(\square)$ Placenta control; $\mathrm{R}=0.946 ; \mathrm{n}=8 ;(\diamond) \mathrm{MCF}-7 ; \mathrm{R}=0.988 ; \mathrm{n}=8$. 


\section{CHIANG ET AL.}

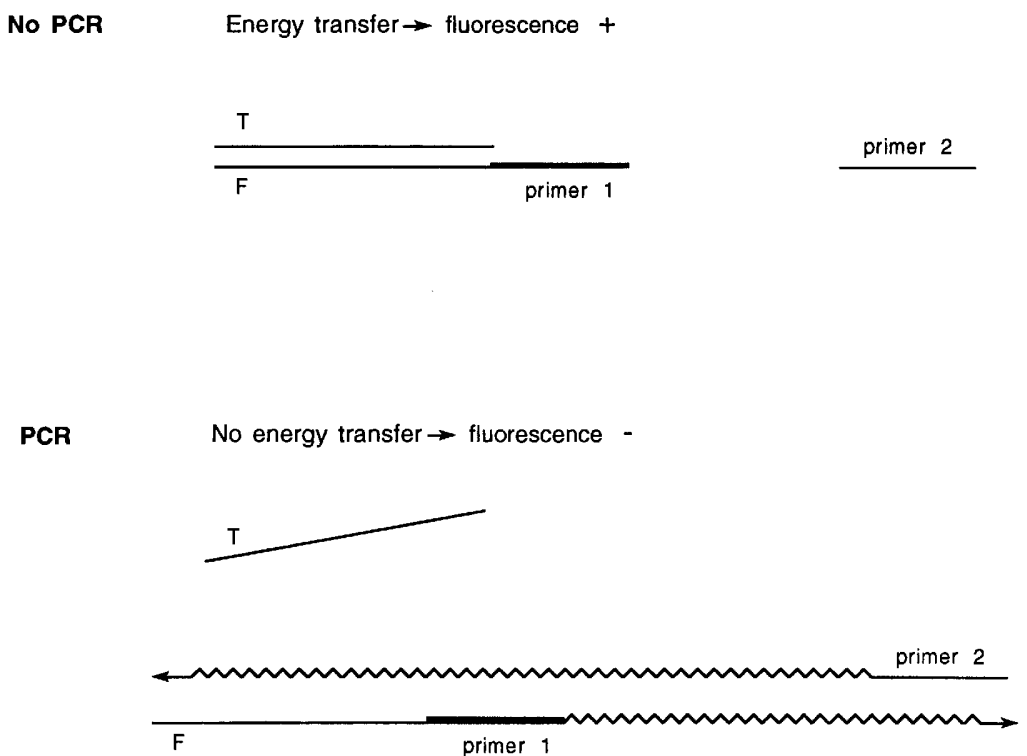

Figure 2 Schematic representation of energy transfer of the AmpliSensor in PCR. Primer 2 is the excess primer in the first PCR reaction. Primer 1 (thick line corresponding to the AmpliSensor) is a nested primer homologous to the PCR product amplified by the first PCR reaction. (F) fluorescein; $(T)$ Texas Red. Energy transfer can only occur when fluorescein and Texas Red are close to each other.

tide duplex. The conditions listed in Methods and the data reported below were obtained using these optimized parameters.

\section{Sensitivity of Fluorescent-PCR Assay}

The sensitivity of the fluorescent PCR-based detection system was compared with the gel PCRbased assay where the product was detected by ethidium bromide staining. For this comparison, we used a human liver cDNA library (Clontech) and primers from the apolipoprotein $\mathrm{C}$ gene (see Methods). The cDNA library was serially diluted up to 256-fold with SM [50 mM Tris (pH 7.5), 0.1 $\mathrm{M} \mathrm{NaCl}, 8 \mathrm{mM} \mathrm{MgSO}_{4}, 0.01 \%$ gelatin] buffer. Figure 3 shows that the gel PCR-based system using detection by ethidium bromide staining reached the detection limit after a 64 -fold dilution. However, the fluorescent PCR-based detection system yielded signal at the 256 -fold dilution (positive at 13 cycles after adding the fluorescent primer; Fig. 3 ). With increasing cycle number, the fluorescent method could detect the presence of the transcript with 1024-fold diluted eluate (data not shown). These data demonstrate that the fluorescent-PCR detection system is more sensitive than the ethidium bromide-gel-based assay by at least fourfold.

\section{Specificity of Fluorescent-PCR Assay}

We chose as substrate six genes that were reported to be tissue-specific on the basis of Northern blotting (sequence for oligonucleotides and tissue localization data generously provided by D. Cupo, Life Technologies, Inc., Gaithersburg, MD; Gruber et al. 1995). We also used a constitutively expressed gene, PKD1 (polycystic kidney disease), as a positive control. The Methods section below gives the primer sequences used for PCR. For the fluorescent-PCR assay, we used a genespecific primer and a vector ( $\lambda$ gt11) primer for the initial asymmetric amplification for 30 cycles; the fluorescent primer was then added, the reaction was allowed to proceed for one PCR cycle, and a baseline fluorescence reading was taken. The reaction was then continued for the indicated number of cycles, a repeat fluorescence reading was taken, and this routine was repeated as appropriate. The salient point is that this methodology yields a dynamic reading of the reaction that permits us to assay the reaction in the exponential cycle phase. This makes the final analysis semiquantitative by determining when the fluorescence decrement for each of two independent reactions is $>0.2$ (we use a fluorescence decrement of $>0.2$ as our benchmark of positive transcription).

PKD1 was expressed constitutively using the fluorescent-PCR assay; albumin was expressed in fetal liver, but not in embryonic liver or in any other tissues examined. These controls demonstrate that the same result was obtained for both the fluorescent-PCR (data not shown) and the gel-based PCR assays of transcription (Buraczynska et al. 1995). The results of the fluorescentPCR assay for the other five genes are given in Table 4 (assayed on even-numbered cycles following addition of the fluorescent oligonucleotide). Our notation is: (3) means the PCR decrement was $>0.2$ in each of duplicate samples after 10 cycles; (2) after 12 or 14 cycles; (1) after 16 cycles; and (-) means the PCR decrement was still $<0.2$ after 16 cycles. Detection at earlier 


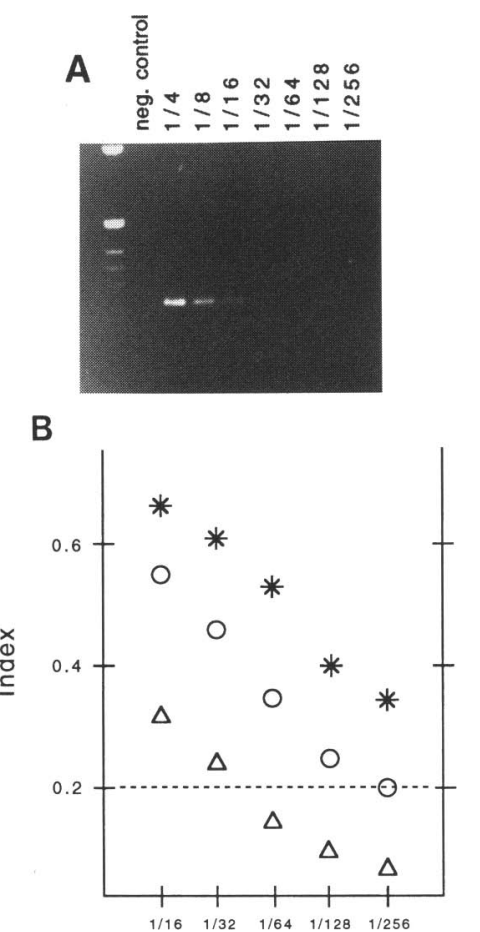

Figure 3 Sensitivity of gel-PCR- and fluorescentPCR-based analyses of transcription. Primers from the apolipoprotein C gene (forward: 5'GGGACGCATGCCTAGCCCGACCTTCCT-3', with the underlined sequence representing the hook complementary to the single-stranded T-strand overhang extending from the fluorescent oligonucleotide duplex; reverse: 5'-GACTCTCCCCTTGTCCACTGATG-3') were used to screen a human liver cDNA library (Clontech; HL3006b) by the gelPCR- and fluorescent-PCR-based methodologies. It can be seen that the gel-based assay using ethidium bromide $(A)$ is positive to a $1 / 64$ dilution, whereas the fluorescent-PCR assay $(B)$ is positive to a $1 / 256$ dilution 13 cycles after adding the fluorescent primer. $(B)(\triangle) 30+10 ;(\bigcirc) 30+13 ;\left(^{*}\right) 30+16$ cycles.

cycles indicates a greater abundance of the gene in question. In all cases, the gene was expressed at its highest abundance in the appropriate cDNA library, that is, liver (fetal and adult) for apolipoprotein $C$; heart (fetal and adult) for cardiac tropo$\operatorname{nin} T$; neural structures for myelin; lymphocytes and monocytes (both of which will include myelomonocytes and platelets) for platelet receptor; and fetal lung for surfactant $D$. Thus, there are no false negatives with the fluorescent-PCR test. In all cases, the PCR-gel test was also positive using Southern blot hybridization for detection of transcription.
Multiple additional cDNA libraries were also positive with each of the probes at the earliest assay cycle at which a positive signal was obtained, except for surfactant $D$ where multiple tissues were positive at the next assay cycle (Table 4). This illustrates that abundant expression occurs in tissues other than those expected. In addition, cDNA libraries from multiple tissues were positive at later cycles, indicating that the sequence of interest is transcribed, albeit less abundantly than in the cDNA libraries positive at earlier cycles. This semiquantitative feature is a useful aspect of this analysis: positivity (fluorescence decrement $>0.2$ ) at lower cycle numbers implies a higher degree of abundance than when positivity first occurs at later cycles. In all five cases, we observed the most abundant transcription in the expected tissues.

Table 4 compares the sensitivity of four methods: the gel-PCR assay monitored by ethidium bromide (Buraczynska et al. 1995; Chiang et al. 1995; Kurnit et al. 1995) or SYBR green (Schneeburger et al. 1995) staining, the gelPCR assay monitored by Southern blotting with the gene in question as a radiolabeled probe, and the fluorescent-PCR assay. For the most abundant expression (defined as positivity in the fluorescent-PCR assay at the minimum number of cycles, including all tissues where transcription was known previously to occur), there was positivity with all four techniques for all 34 tissues. This underscores the ability of the fluorescentPCR technique to substitute successfully for the PCR-gel technique. After the optimization (see Methods), the fluorescent-PCR method was more sensitive than the standard gel-PCR assay using ethidium bromide, as shown by our control experiment with apolipoprotein $C$ and further documented by Table 4 , which contains more cases where the fluorescent-PCR assay was positive but the gel-based PCR assay was negative than vice versa. Follow-up studies with SYBR green (Schneeburger et al. 1995) demonstrate that this dye is also more sensitive than ethidium bromide, yielding sensitivity equivalent to the fluorescent-PCR method. The order of sensitivity of the methods (Table 4) was Southern blot $>$ fluorescent-PCR $=$ gel-PCR detected by SYBR green $>$ gel-PCR detected by ethidium bromide. Although it is not feasible to use the Southern blotting assay routinely, it confirmed the results obtained by the other assays, as it was always positive when any of the other methods was positive. The accuracy of the assay is further 
Table 4. Semiquantitative Analysis of Transcription by Fluorescent-PCR

\begin{tabular}{|c|c|c|c|c|c|}
\hline & Apolipoprotein C & $\begin{array}{l}\text { Platelet } \\
\text { receptor }\end{array}$ & $\begin{array}{l}\text { Myelin } \\
\text { basic protein }\end{array}$ & $\begin{array}{l}\text { Cardiac } \\
\text { troponin } \mathrm{T}\end{array}$ & Surfactant D \\
\hline Aorta & $+/-1+/ 2$ & $+1-1+1-$ & $+/-/+/ 3$ & $-1-1-1$ & $-1+1-1-$ \\
\hline Bone marrow & $-1-1+1-$ & $+/+/+/ 1$ & $-1+1+/ 2$ & $-1-1+12$ & $-1-1+1-$ \\
\hline Brain, amygdala & $+/+/+/ 2$ & $+/+/+/ 1$ & $+/+1+/ 3$ & $+/+/+/ 3$ & $+/+/+/ 2$ \\
\hline Brain, cingulate gyrus & $+/+/+1-$ & $-1-1-1-$ & $+/+/+/ 3$ & $+/+/+/ 2$ & $+/+/+/ 2$ \\
\hline Brain, cerebral cortex & $-1+1-1-$ & $-1-1-1-$ & $+/+/+/ 3$ & $+/+/+/ 2$ & $+/+/+/ 2$ \\
\hline Brain corpus callosum & $+/+/+/ 2$ & $+1-/+/ 2$ & $+/+/+/ 3$ & $+/+/+/ 2$ & $+/+1+1-$ \\
\hline Brain, hypothalamus & $-1-1+1-$ & $+/+/+/ 1$ & $+/+/+/ 3$ & $-1-1-1-$ & $-1-1-1-$ \\
\hline Brain, substantia nigra & $+/+/+/ 2$ & $+/+/+/ 1$ & $+/+/+/ 3$ & $+/+/+/ 2$ & $-1+1+1-$ \\
\hline Brain, subthalamic nucleus & $-1+1-1-$ & $+/+/+/ 1$ & $+/+/+/ 3$ & $-1-1-1-$ & $-1+1+1-$ \\
\hline Breast & $-1-1-1-$ & $-1-1-1-$ & $-1-1-1-$ & $-1-1+1-$ & $-1-1-1-$ \\
\hline Breast carcinoma & $-1-1-1-$ & $-/+/+/ 1$ & $-1-1-1-$ & $-1-1+1-$ & $-1-1+1-$ \\
\hline Colon 1 & $-1-1-1-$ & $+/+/+/ 2$ & $-1-1-1-$ & $-1-1+1-$ & $-1-1-1-$ \\
\hline Colon 2 & $-1-1-1-$ & $+/+/+/ 1$ & $+/+/+/ 3$ & $-1-1-1-$ & $-1-1+1-$ \\
\hline Colon adenocarcinoma & $-1-1+1-$ & $-1-1-1-$ & $-1-1-1-$ & $-1-1-1-$ & $+/+/+1-$ \\
\hline Colorectal adenocarcinoma & $-1-1-1-$ & $+/+/+/ 1$ & $+/+/+/ 2$ & $+/+/+/ 2$ & $-1-1+/ 2$ \\
\hline Endothelial 1 & $-1-1-1-$ & $+/+/+/ 2$ & $-1-1+1-$ & $-1-1+1-$ & $-1-1+1-$ \\
\hline Endothelial 2 & $-1-1-1-$ & $-1-1-1-$ & $-1-1-1-$ & $-1-1-1-$ & $-1-1-1-$ \\
\hline Epidermis & $-1-1-1-$ & $-1-1-1-$ & $+/+/+/ 2$ & $+/+/+/ 2$ & $-1-1+1-$ \\
\hline Eye & $-1-1-1-$ & $-1-1-1-$ & $+/+/+/ 3$ & $-1-1-1-$ & $-1-1-1-$ \\
\hline Fat cell & $-1-1+/ 2$ & $+/+/+/ 2$ & $+/+/+/ 3$ & $+1-1+12$ & $-1+1+1-$ \\
\hline Fetal adrenal & $+/+/+/ 2$ & $-1-1-1-$ & $-1+1-1-$ & $-1-1-1-$ & $-1-1+1-$ \\
\hline Fetal brain & $-1-1-1-$ & $-1-1-1-$ & $+/-/+/ 2$ & $-1-1-1-$ & $-1+1+12$ \\
\hline Fetal heart & $-1-1-1-$ & $+/-/+/ 1$ & $+/+/+/ 2$ & $+/+1+/ 3$ & $-1+1+1-$ \\
\hline Fetal kidney & $+/+/+/ 3$ & $+/+/+/ 1$ & $-1-1-1-$ & $-1-1-1-$ & $+/+/+/ 2$ \\
\hline Fetal liver & $+/+/+/ 3$ & $-1+1+1-$ & $-1-1+1-$ & $-1-1-1-$ & $-1-1-1-$ \\
\hline Fetal lung & $-1-1-1-$ & $+/+/+/ 2$ & $-1-1-1-$ & $+1-1+1-$ & $+/+/+/ 3$ \\
\hline Giloma & $+/+/+/ 3$ & $-1-1-1-$ & $+/+/+/ 3$ & $+/+/+/ 3$ & $+/+/+/ 2$ \\
\hline Heart & $-1-1-1-$ & $+1-1+1-$ & $+/+/+/ 3$ & $+/+/+/ 3$ & $-1-1+1-$ \\
\hline Keratinocyte 1 & $-1-1-1-$ & $+/+/+/ 2$ & $-1-1+1-$ & $-1-1-1-$ & $-1-1-1-$ \\
\hline Keratinocyte 2 & $-1-1+1-$ & $+/+/+/ 1$ & $-1-1+12$ & $-1+/+12$ & $-1+1+1-$ \\
\hline Kidney & $-/-/+/ 1$ & $-1-1+1-$ & $-1-1+1-$ & $+/+/+/ 2$ & $-1-1-1-$ \\
\hline Leukemia & $-1-1-1-$ & $-1-1-1-$ & $-1+1-1-$ & $-1-1-1-$ & $-1-1-1-$ \\
\hline Leukocyte & $-1-1+1-$ & $-1-1-1-$ & $-1-1-1-$ & $-1-1-1-$ & $-1-1+1-$ \\
\hline Liver & $+1+1+/ 3$ & $-/-/+/ 1$ & $-1+1+1-$ & $-1-1+1-$ & $-1-1-1-$ \\
\hline Lung & $+/+/+/ 2$ & $+1+1+/ 2$ & $+/+1+1-$ & $+/+/+/ 2$ & $+/+/+/ 2$ \\
\hline Lymphocyte & $-1-1-1-$ & $+/+/+/ 2$ & $-1-1-1-$ & $-1-1-1-$ & $-1-1-1-$ \\
\hline Melanoma & $-1-1+1-$ & $-1-1+1-$ & $+/+/+/ 2$ & $-1-1-1-$ & $-1-1+1-$ \\
\hline Monocyte & $-1-1-$ & $+/+/+/ 2$ & $-1-/+/ 2$ & $-1-1+1-$ & $-1-1-1-$ \\
\hline Osteosarcoma & $-1-1-1-$ & $-1-1+1-$ & $-1+1-1-$ & $-1-1-1-$ & $-1-1-1-$ \\
\hline Ovary & $-1-1-1-$ & $-1-1-1-$ & $-1-1-1-$ & $-1-1-1-$ & $-1-1-1-$ \\
\hline Pancreas & $-1-1-1-$ & $-1-1-1-$ & $+/+1+1-$ & $-1-1-1-$ & $-1-1+1-$ \\
\hline Pituitary gland & $-1+1+1-$ & $-1-1+1-$ & $-/+1+/ 2$ & $-1-1-1-$ & $-1-1-1-$ \\
\hline Placenta & $+1+1+/ 3$ & $-1-1-1-$ & $-1-1-1-$ & $+/+/+/ 3$ & $-1-1+1-$ \\
\hline Skin fibroblast & $-1-1-1-$ & $-1-1-1-$ & $+/+/+/ 2$ & $+/+/+/ 3$ & $-1+1+1-$ \\
\hline Negative control $(\lambda)$ & $-1-1-1-$ & $-1-1-1-$ & $-1-1-1-$ & $-1-1-1-$ & $-1-1-1-$ \\
\hline \multicolumn{6}{|c|}{$\begin{array}{l}\text { The transcription patterns of five genes in } 44 \text { CDNA libraries (Clontech) is given. The first three columns describe whether signal } \\
\text { was obtained by the gel-PCR method analyzed by ethidum bromide (first column), SYBR green (Schneeberger et al. 1995; second } \\
\text { column), or Southern ( } 1975 \text { ) blotting (third column). The fourth column summarizes the results obtained by the fluorescent-PCR } \\
\text { method. The numbers in this column indicate cycle numbers by which a fluorescent decrement }>0.2 \text { was achieved in each of two } \\
\text { replicate PCR reactions (see Methods for reaction conditions). ( } 3 \text { ) This decrement was achieved by } 10 \text { cycles after adding the } \\
\text { fluorescent primers; (2) this decrement was achieved by } 12 \text { or } 14 \text { cycles; (1) this decrement was achieved by } 16 \text { cycles; ( }- \text { ) means } \\
\text { this decrement was not achieved by } 16 \text { cycles. As expected, the } \lambda \text { negative control uniformly gave no signal with any of the } \\
\text { methods. }\end{array}$} \\
\hline
\end{tabular}


supported by the finding that the size of the PCR product detected by ethidium bromide, SYBR green, or Southern blotting was always the expected size.

\section{DISCUSSION}

\section{Quantitative Analysis of PCR}

Quantitative PCR has the following advantages: (1) It is not necessary to have informative polymorphic markers, which permits the direct application of any set of unique markers (including intragenic markers from the target of interest) for the analysis of gene copy number; (2) both deletions and amplifications are scored using the same reaction; (3) only a small amount of sample is required for this PCR-based analysis.

The AmpliSensor assay monitors PCR by fluorescence decrement observed in real time that permits quantitation. In the duplex state, energy transfer between two fluorophores on different strands of an oligonucleotide duplex (AmpliSensor) abutting a primer is high. Disruption of this duplex via PCR yields decreased energy transfer between the fluorophores. As a result, PCR correlates directly with decreased fluorescence output (Fig. 2). The singular ability to monitor a quality each cycle that varies with PCR appropriately during the exponential phase of the PCR reaction enables this technique to perform quantitation.

In contrast, other variants of quantitative PCR involve densitometric analyses of PCR product with a necessary effort made to seeing the bands of interest when the reaction is still in the exponential phase (for most recent use of quantitative PCR, see Inoue et al. 1996). Even with the most recent improvements, quantitative PCR using gel-based analyses requires careful use of an appropriate number of PCR cycles (which must be worked up separately for each set of probes), requirements of polymorphism to confirm the analysis, and a requirement that PCR with one set of primers does not interfere with PCR using a second set of primers. All of these problems are eliminated by fluorescent PCR where the unknown and control sequences do not have to amplify in the same cycle, and where polymorphism is not required; thus, in our fluorescent-PCR methodology, all single copy sequences are informative in all cases.

\section{Quantitative Analysis: Gene Copy Number}

We used this methodology to assay the sequence copy number of a locus on chromosome 21 , $S 100 \beta$, that had been shown by quantitative Southern blotting to be present in one, two, or three copies in different subjects. In all cases, the fluorescent PCR technique successfully assayed the copy number of $S 100 \beta$. In addition, we successfully detected known deletions of p53 in T-47D cells and of erbB-2 in MCF-7 cells, respectively (Nigro et al. 1989; Szollosi et al. 1995). These values that agree with previous analyses underscore the usefulness of this technique for molecular analysis of copy number anomalies.

We then applied the AmpliSensor method to screen for genome instability on chromosome 17 from the MCF-7 cell line. The chromosome 17 markers p53, BRCA1, SUPT4H, and SUPT6H [two yeast chromatin structural protein homologs we isolated (Chiang et al. 1996a,b)] were analyzed. The SUPT6H marker showed normal dosage with two copies in the MCF-7 cell line. In contrast, we only detected one copy of $p 53$ (which is known to be intact; Casey et al. 1991) in MCF-7 cells. The SUPT $4 H$ and BRCA1 markers were amplified threefold ( 6 copies) in MCF-7 cells. Because both $B R C A 1$ and SUPT4H were amplified similarly ( -6 copies total), these two genes may lie on the same amplicon in this cell line. If this is the case, the amplicon must be large because these two markers are at least several hundred kilobases apart (data not shown). Regardless of the mechanism of amplification of SUPT $4 H$ and BRCA1, we detected successfully both amplifications and deletions with the AmpliSensor method. This underscores the usefulness of this PCR-based technique as it can score and quantitate all amplifications and deletions at the single copy sequence of interest.

An unexpected subtlety has arisen with regard to our BRCA1 results in MCF-7 cells. Although we see amplification of $B R C A 1$ to $\sim 6$ copies (Table 2), Holt and coworkers have shown by polymorphism analysis that only one chromosome bearing BRCA1 is present in MCF-7 cells (Holt et al. 1996). In addition, the cDNA sequence of $B R C A 1$ is normal in these cells (A. Futreal, pers. comm.). Thus, in these cells, BRCA1 function remains unclear. Additional work on tumors (that are not established cell lines) is required to elucidate what role amplification of a single haplotype plays in carcinogenesis. In any event, this does not vitiate our salient finding that BRCA1 and SUPT4H are amplified in this cell line.

The availability of a rapid and sensitive 


\section{CHIANG ET AL.}

method to assay sequence copy number in the genome (amplification or deletion of specific genes) provides a generalized molecular tool to probe the role that genome instability plays in both dysmorphology and oncogenesis. This is especially true for syndromes in which genome instability is relevant etiologically. By way of example, these include the following. (1) A variety of syndromes resulting from to chromosome aneusomy, such as Down syndrome (Scoggin and Patterson 1982). (2) A variety of malignancies associated with deletions and amplifications of genomic material. (Our examination of MCF-7 cells indicates that amplifications may be more pervasive than previously thought in cancer cells. Determination of the validity of this point will require examination of tumors rather than established tumor cell lines.) (3) CMT1A (a result of triplication of the PMP22 gene) and HNPP (a result of deletion of the PMP22 gene), with this copy number mechanism responsible for $>90 \%$ of cases (Dyck et al. 1993). [This genome instability results from mariner-like transposon sequences on both sides of the PMP22 gene (Reiter et al. 1996)]. (4) The DiGeorge Syndrome, in which microdeletion of chromosome 22 is observed in $>85 \%$ of cases [del(22) (q11.21 $\rightarrow \mathrm{q} 11.23)]$ and in which even finer deletions may be responsible for the phenotype in the remainder of cases (Driscoll et al. 1992). (5) Thalassemias resulting from deletion of $\alpha$-globin or $\beta$-globin genes (Kan 1980).

Because the AmpliSensor assay is facile, capable of detecting both deletions and amplifications, and universally successful for detecting sequence copy number alterations, it represents the method of choice for detecting genome instability. As the Genomic Initiative yields an increasing number of mapped unique STS and EST markers, these can all be utilized to map the extent of various genome copy alterations with this assay. The facility of this assay will make it possible to determine what role genome instability plays in both the normal cell and in abnormal disease states.

\section{Semiquantitative Analysis: Transcriptional Abundance}

Six control genes, each previously thought to be expressed uniquely in a specific tissue, and a seventh ubiquitously expressed control gene, were screened against >40 cDNA libraries. In all cases, the genes were expressed most abundantly in the expected tissues. However, transcription was lim- ited to the expected tissue in only one case, illustrating the marked sensitivity and speed of this method and the inability of previous methods both to examine many tissues and to readily diagnose less abundant transcription.

One of the unavoidable limitations of this technique is that the expression pattern is derived from cDNA libraries and will be subject to any artifacts engendered by cDNA cloning and library amplification. Fortunately, this is an analytical rather than a preparative technique, so generation of chimeras by cocloning events is still recorded correctly as successful transcription. Contamination by genomic DNA of the size range $\left(-10^{3} \mathrm{bp}\right)$ that is cloned into cDNA libraries is rare and would yield extremely nonabundant transcription in a tiny fraction of cDNA libraries (at a generous $1 \%$ level of contamination of the cDNA size range with genomic DNA, $10^{6}$ clones/ library and $10^{3}$ bp long insert size, only $1 / 300$ of libraries would have one copy of the relevant genomic DNA). Contamination by genomic DNA resulting in the amplification of introns was not detected by the gel-PCR ethidium bromide, SYBR green, or Southern blotting methods, further demonstrating that genomic DNA contamination is not a significant problem. In addition, albeit impractical for large-scale screening, the Southern blotting method confirmed the accuracy of positive results obtained by the fluorescent-PCR and the original gel-based PCR method (Buraczynska et al. 1995; Chiang et al. 1995; Kurnit et al. 1995); no false positives were observed and the only potential false negatives involved rarer messages. For abundant messages [denoted as (3) in the last column of Table 4], there is essentially complete concordance, with all four methodologies being positive. Using the intensity of the band obtained, the estimate of abundance obtained by SYBR green parallels that obtained by fluorescent PCR. Thus, these methods are essentially equivalent in both sensitivity and informativeness.

The expression patterns of all seven probes were consistent with previous analyses of major transcription patterns, with each of the seven probes expressed at the highest levels in the expected tissues (essentially no false negatives in tissues with abundance level 3). This illustrates that great confidence can be placed in the ability of the assay to detect abundant and moderately abundant transcription in a given library. At the lower end of abundance, a negative reduces transcription of a gene to be less than a baseline 
reading but cannot definitively rule out nonabundant or leaky transcription. Nevertheless, it rules out abundant or moderately abundant levels of transcription. Conversely, we do not know whether a low-level of transcription (e.g., seen with the fluorescent-PCR technique only after 16 cycles) is significant or whether it reflects "leakiness" of transcriptional control.

The availability of this technique affords a special opportunity to merge with recently reported technologies to isolate sequences expressed differentially in two different tissues (Schena et al. 1995; Velculescu et al. 1995). Once such sequences are isolated by these technologies, primers corresponding to those sequences can be synthesized and the fluorescent-PCR or SYBR green-gel methodology can then be used to describe a semiquantitative analysis of transcription in a large number of cDNAs. If needed, extension of the fluorescent-PCR technique using a control (e.g., G3PDH) may be accomplished to make the reaction fully quantitative (Table 3 ).

In sum, fluorescent PCR can be used to accomplish both quantitative and less intricate semiquantitative analyses. Quantitation of sequences in the genome will be useful to diagnose genetic copy number syndromes and changes in copy number that accompany cancers. Semiquantitation of expressed sequences will be useful to catalog levels of transcript expression in cDNAs.

\section{METHODS}

\section{Principle of AmpliSensor Assay}

The AmpliSensor assay has been described (Wang et al 1995). The assay is based on the principle that decrement of fluorescence energy transfer can be used to measure PCR-mediated disruption of an oligonucleotide duplex, the "AmpliSensor" (Fig. 2). The two strands of the oligonucleotide duplex are modified with donor and acceptor fluorophores, respectively. In the native duplex state that results from the absence of $\mathrm{PCR}$, energy transfer between the fluorophores (the donor, fluorescein, and the receptor, Texas Red) is efficient; the fluorescent signal at the emission frequency of Texas Red following stimulation at the excitation frequency for fluorescein is high. PCR disrupts this oligonucleotide duplex due to strand displacement, decreasing energy transfer [which varies inversely with the sixth power of the distance between the two fluors (Wang et al. 1995)]. The extent of disruption, which depends directly on the amount of PCR that occurs, can be quantified directly and accurately by measuring the decrement in fluorescence that results from decreased energy transfer.

To measure the genomic copy number of a target sequence in a given cell type, the fluorescence decrement of the target sequence is divided by the fluorescence decre- ment of a reference sequence with DNA from the given cell type; this fraction is then divided by the ratio between the fluorescence decrement of the target sequence divided by the fluorescence decrement of the reference sequence with normal DNA (the copy number of the target and reference sequences in normal genomic DNA and the copy number of the reference sequence in normal genomic DNA are all known). This yields the desired copy number of the target sequence in the given cell, normalized for the relative efficiencies of the PCR reactions for the target and reference sequences. Note that because only ratios in a given cell are required, it is not necessary to quantitate precisely the amount of cells used for derivation of the ratios.

\section{Assay Procedure}

PCR was performed in a 96-well plate (PTC-100, MJ Research) and directly analyzed in situ for energy transfer using a microplate fluorimeter controlled by a workstation (Biotronics Corp., Lowell, MA). To quantify the decrease in energy transfer, fluorescence readings from each reaction were compared with readings from a control reaction without polymerase. This control provided a reference for the maximum initial fluorescent signal, because PCR did not occur. To compensate for well-to-well variations among the PCR reactions in the plate, all data were normalized using an initial reading (base reading) taken one cycle after adding the AmpliSensor.

Quantitative analysis requires reproducibility so that each reaction was repeated multiple times. Only $\mathrm{H}_{2} \mathrm{O}$ was added to the blank well. For the apex well, everything except Taq DNA polymerase was added. For the negative well, everything except genomic DNA was added. The first PCR reaction (asymmetric PCR profile) was accomplished; this was required to generate sufficient template for the second PCR reaction; use of a nested PCR system also serves to increase the fidelity of the PCR reaction. The second (nested) PCR reaction was then initiated by adding a nested third, partially duplex, primer carrying an AmpliSensor oligonucleotide duplex (Wang et al. 1995) with fluorescein on one strand and Texas Red on the other strand. The initial asymmetric PCR was performed in $10 \mu \mathrm{l}$ of $50 \mathrm{~mm}$ Tris- $\mathrm{HCl}$ (pH 8.7), $50 \mathrm{mM} \mathrm{KCl,} 5 \mathrm{mM} \mathrm{NH}_{4} \mathrm{Cl}, 5 \mathrm{mM}$ $\mathrm{MgCl}_{2}, 1$ mм DTT, $0.1 \%$ Triton X-100, $0.2 \mathrm{U}$ of Taq DNA polymerase, $90 \mathrm{ng}$ of excess primer, and $12 \mathrm{ng}$ of limiting primer. The genomic DNAs were in the range of $5 \times 10^{2}$ to $1 \times 10^{4}$ copies per $\mu \mathrm{l}$ of the DNA sequence to be amplified, using $50 \mathrm{ng} / \mu \mathrm{l}$ of yeast tRNA as the dilution solution. An aliquot of $2.5 \mu \mathrm{l}$ from each dilution was used for PCR. The asymmetric PCR profiles for (1) BRCA1, (2) erbB-2 and SUPT4H, (3) SUPT6H, and (4) S1OO $\beta$ were: (1) $95^{\circ} \mathrm{C}, 25 \mathrm{sec}$; $58^{\circ} \mathrm{C}, 30 \mathrm{sec}$; and $72^{\circ} \mathrm{C}, 30$ sec for 19 cycles; (2) $95^{\circ} \mathrm{C}, 25$ sec; $58^{\circ} \mathrm{C}, 30 \mathrm{sec}$; and $72^{\circ} \mathrm{C}, 40 \mathrm{sec}$ for 24 cycles; (3) $95^{\circ} \mathrm{C}$, $25 \mathrm{sec} ; 55^{\circ} \mathrm{C}, 30 \mathrm{sec}$; and $72^{\circ} \mathrm{C}, 30 \mathrm{sec}$ for 24 cycles; (4) $95^{\circ} \mathrm{C}, 25 \mathrm{sec} ; 60^{\circ} \mathrm{C}, 30 \mathrm{sec}$; and $72^{\circ} \mathrm{C}, 40 \mathrm{sec}$ for 24 cycles. After the asymmetric PCR, $5 \mu \mathrm{l}$ of AmpliSensor $(1 \mathrm{ng} / \mu \mathrm{l})$ in reaction buffer was added to the reactions (except the blank reaction) and the PCR was continued with the AmpliSensor profile. The AmpliSensor profiles for (1) BRCA1, (2) erbB-2 and SUPT4H, (3) SUPT6H, and (4) $S 100 \beta$ were: (1) $95^{\circ} \mathrm{C}, 25 \mathrm{sec} ; 62^{\circ} \mathrm{C}, 30 \mathrm{sec}$; and $72^{\circ} \mathrm{C}, 30 \mathrm{sec}$; (2) $95^{\circ} \mathrm{C}, 25$ $\mathrm{sec} ; 62^{\circ} \mathrm{C}$, $30 \mathrm{sec}$; and $72^{\circ} \mathrm{C}, 40 \mathrm{sec} ;(3) 95^{\circ} \mathrm{C}, 25 \mathrm{sec} ; 60^{\circ} \mathrm{C}$, $30 \mathrm{sec}$; and $72^{\circ} \mathrm{C}, 40 \mathrm{sec}$; $(4) 95^{\circ} \mathrm{C}, 25 \mathrm{sec} ; 62^{\circ} \mathrm{C}, 30 \mathrm{sec}$; and $72^{\circ} \mathrm{C}, 40 \mathrm{sec}$. The reaction was followed dynamically by 


\section{CHIANG ET AL.}

monitoring fluorescence following the addition of the AmpliSensor. The reaction is performed as two sequential nested PCR amplifications to increase the specificity and to enable enough sequence to accumulate in the first reaction to enable quantitative PCR using the fluorescent AmpliSensor to proceed expeditiously upon adding the AmpliSensor.

\section{Data Analysis}

Data were analyzed using ASAP software (Biotronics Corp., Lowell MA); the principle of this software is outlined below. The AG-9600 AmpliSensor Analyzer (Biotronics Corp.) monitors the fluorescent signal of each reaction via a bottom reading mechanism. The signal reading thus acquired is registered in digital format and processed according to a default algorithm, which converts the raw reading into a normalized data set for standard curve interpolation. The fluorescent-PCR assay requires both the basereading data set and the assay-cycle data set for quantitation. The base-reading data set represents the initial signal reading acquired prior to any detectable PCR-induced signal changes, whereas the assay-cycle data set consists of signal readings measured after any number of user-selected PCR cycles (the microtiter dish with the samples undergoing PCR is alternately placed in a thermocycler and the fluorescence plate reader, thereby allowing alternate polymerization and reading). The readings of each data set are normalized, allowing determination of PCR by the decrease in fluorescence resulting from PCR. The well-to-well signal variation intrinsic to each data point comes mainly from factors such as geometric irregularity of microplate and pipetting related inaccuracy. This signal interference can be eliminated through a normalization process using the base reading, which takes into account both the background noise and the energy transfer coefficient. The detection index derived from the normalized data is equivalent to the signal departure of each sample from that of the negative standard. Thus, the value of the detection index reflects the relative amount of amplified target.

Quantitative analysis yields the amount of target sequence present in the sample based on the linear regression fitting curve derived from a set (at least three dilutions) of positive standards. Linear regression fitting is based on the principle of least mean square analysis to correlate the quantity and detection index using the linear equation derived from the positive standard set. To optimize the fitting, the program intentionally discards those standards deviating the most from the linearity (ASAP software; Biotronics Corp.). Because both the sequence to be investigated and the reference sequence are measured both in the cell line to be investigated and in a control cell line, the quantity of DNA from a given cell line does not factor into the final result, thereby obviating the need to perform precise measurement of the DNA concentrations from the cell lines to be analyzed.

\section{PCR Primers for Measurement of Genomic Sequence Copy Number}

The sequences of limiting, excess, and AmpliSensor primers for (1) BRCA1 (chromosome 17), (2) SUPT4H (chromosome 17), (3) SUPT6H (chromosome 17), (4) erbB-2 (chromosome 17), (5) S10Oß (chromosome 21) and (6) IGF-1 (chromosome 12) are as follows: (1) BRCA1: limiting: 5'-CCCAGAGTCAGCTCGTGTTG-3', excess: 5'GGGTCAGGCCAGACACCACCATGG-3', AmpliSensor: 5'-AATTGACAGCTTCAACAGAAAGG-3'; (2) SUPT4H: limiting: 5'-AAGGTGGCAGCTGAGTGG-3', excess: 5'CTGAGTCTGAATTGGAGG-3', AmpliSensor: 5'-CTGCTTATTTCTTGTTCTGG-3'; (3) SUPT6H: limiting: 5'-GAGCACTGTGATGATGAAGC-3', excess: 5'-ATGCTTTAATGAACCTTATC-3', AmpliSensor: 5'-TTGGAGGAAGCCCAGGGCATTGC-3'; (4) erbB-2: limiting: 5'-ACTGAAAGCCTTAGGGAAGC-3', excess: 5'-AAGCACTCTGTACAAAGCCTGG-3', AmpliSensor: 5'-TACTGCCCCCCATGAGGAAGGAAC-3'; (5) S100ß: limiting: 5'-CTGACCACTTCCCCAGAGTGG-3', excess: 5'-GCTGGGCCCTCCTGCTGAACG-3', AmpliSensor: 5'-TACACCTGTGCTTAGGGCACTG-3'; (6) IGF-1: limiting: 5'-GATGAGGCAAAGACTATGCCG-3', excess: 5'-CCCAGGTACCCTTCTCCCAGAGTGG-3', AmpliSensor: 5'-TACTAGGCTGCCTGTCACTGTC-3'.

\section{Cell Culture and Genomic DNA Isolation}

The MCF-7 cell line (breast adenocarcinoma; ATCC HTB22) was maintained in minimal Eagle's medium with nonessential amino acids and Earle's balanced salt solution, 1 mM sodium pyruvate, $10 \mu \mathrm{g} / \mathrm{ml}$ of bovine insulin, and $10 \%$ fetal calf serum. The T-47D cell line (ductal breast carcinoma; ATCC HTB-133) was maintained in RPMI 1640 with 0.2 units bovine insulin $/ \mathrm{ml}$ and $10 \%$ fetal calf serum. Genomic DNAs were isolated using the AcuGen DNA Extraction kit (Biotronics Corp.).

\section{Semiquantitative Analysis of Transcription}

Oligonucleotide primers to be ligated to the F-strand of the oligonucleotide duplex (Fig. 2) were purified following synthesis by incubating at $37^{\circ} \mathrm{C}$ for $1 \mathrm{hr}$ in the presence of $0.01 \mathrm{M} \mathrm{MgCl}_{2}$ followed by ethanol precipitation [3 volumes of ethanol and $0.3 \mathrm{M}$ sodium acetate ( $\mathrm{pH}$ 5.6)]. Based on $A_{260} / A_{280}$, this purification procedure yielded DNA as pure as that prepared by a conventional phenol/ chloroform extraction method followed by ethanol precipitation. The $5^{\prime}$ end of the primer was phosphorylated with $\mathrm{T} 4$ polynucleotide kinase in the presence of $1 \mathrm{~mm}$ ATP for $1 \mathrm{hr}$ at $37^{\circ} \mathrm{C}$. Then 90 pmole of the phosphorylated primers were ligated with $10 \mu \mathrm{l}$ of the AmpliSensor mixture to generate a final volume of $50 \mu \mathrm{l}$ which contained a duplex of an F-strand and a T-strand ( 9 pmole $/ \mu$ l each) (Biotronics Corp.). Ligation of the primer to the F-strand is facilitated by the presence of a 7-bp "hook" sequence (5'GGGACGC-3'; underlined) at the $5^{\prime}$ end of the primer complementary to a 7-bp sequence on the $5^{\prime}$ end of the T-strand ( $5^{\prime}$-GCGTCCC- $\left.3^{\prime}\right)$. These ligations were carried out for $1 \mathrm{hr}$ at $16^{\circ} \mathrm{C}$ followed by inactivation of T4 DNA ligase enzyme for $10 \mathrm{~min}$ at $65^{\circ} \mathrm{C}$. The fluorescent primers were then used for PCR without further purification. The ligation efficiency was measured as described (Wang et al. 1995), being typically $>95 \%$ for the fluorescent oligonucleotide duplex. The oligonucleotides carrying the $\mathrm{F}$ and T fluors were from Biotronics (Wang et al. 1995); the 


\section{FLUORESCENT-PCR REACTION}

T-strand was complementary to the underlined $7 \mathrm{bp}$ at the 5 '-most end of the primers listed below.

The sequences of the primers were: $\lambda g t 11$ forward: 5'-CCTGGAGCCCGTCAGTATCGGCGG-3'; apolipoprotein $C$ : forward, 5'-GGGACGCATGCCTAGCCCGACCTTCCT3'; reverse, 5'-GACTCTCCCCTTGTCCACTGATG-3'; platelet receptor: forward, 5'-GGGACGCACTACCAAAACCAGGGCAACT-3'; reverse, 5'-TGATGAGGAAGACCAGGAAGA-3'; myelin C: forward, 5'-GGGACGCGCACAGAGACACGGGCATCCTT-3'; reverse, 5'-GTGCGAGGCGTCACAATGTTCTT-3'; cardiac troponin T: forward, 5'GGGACGCACCGAGGAGACCAGGGCAGAA-3'; reverse, 5'-GCGCTTCCGGTGGATGTCAT-3'; surfactant $D$ : forward, 5'-GGGACGCAATGGCCAAAGTGTCGGGGAGAA3'; reverse, 5'-TGGCTCAGAACTCGCAGACCACA-3'; PKD1: forward, 5'-GGGACGCTCTTGCTACCTGGCCTGG3'; reverse, 5'-ACTATTTTCACTAGGGCTGAGGG-3'; albumin: forward, 5'-GGGACGCGCCTACCATGAGAATAAGAG-3'; reverse, 5'-GAAATCCTCTACCGAAGTGG3 '. In each case, the oligonucleotide with the "hook" sequence, 5'-GGGACGC-3' (underlined) was used for both fluorescent PCR and for gel-based PCR.

\section{PCR and Analysis of the Abundance Assay}

PCR for the abundance assay was carried out in a 96-well plate with the PTC-100 machine (MJ Research Inc., Watertown, MA). For fluorescent PCR, the initial asymmetric preamplification with $\lambda$ gt11 forward $(0.05 \mu \mathrm{M})$ and the specific reverse primer $(2 \mu \mathrm{M})$ was performed in a $10 \mu \mathrm{l}$ reaction mixture containing $1 \mu \mathrm{l}$ of cDNA library eluate $\left(-10^{7} \mathrm{pfu}\right.$, Clontech), 1 unit of Taq DNA polymerase, and $0.2 \mathrm{~mm}$ (of each) dNTP in Taq Extender buffer [20 mM Tris- $\mathrm{HCl}(\mathrm{pH} 8.8), 10 \mathrm{~mm} \mathrm{KCl}, 10 \mathrm{~mm}\left(\mathrm{NH}_{4}\right)_{2} \mathrm{SO}_{4}, 2 \mathrm{~mm}$ $\mathrm{MgSO}_{4}, 0.1 \%$ Triton X-100, and $0.1 \mathrm{mg} / \mathrm{ml}$ of nuclease-free bovine serum albumin]. The PCR protocol was: initial denaturation at $94^{\circ} \mathrm{C}$ for $2 \mathrm{~min}$, followed by 30 cycles of denaturation at $92^{\circ} \mathrm{C}$ for $40 \mathrm{sec}$, annealing at $60^{\circ} \mathrm{C}$ for 40 sec, and extension at $75^{\circ} \mathrm{C}$ for $2 \mathrm{~min}$. For the nonfluorescent gel-based assay, two specific primers (final concentration $0.5 \mu \mathrm{M}$ ) were used for 30 cycles of amplification. After PCR, the samples were run on a $3 \%$ agarose gel followed by ethidium bromide staining or SYBR green (Schneeburger et al. 1995) staining, respectively. The procedure for Southern (1975) blotting onto Hybond-N nylon membrane was performed according to Amersham's protocol.

Nested fluorescent-PCR was performed by preamplifying as above with one gene-specific primer and an anchored ( $\lambda$ gt1 1 forward) primer. Following 30 cycles, $5 \mu$ l of fluorescent primer mixture ( 1 pmole $\rightarrow 67 \mathrm{~nm}$ final concentration) was added $(0.6 \mu \mathrm{l}$ of fluorescent primer, $0.5 \mu \mathrm{l}$ of $10 \times$ Taq Extender buffer, and $3.9 \mu \mathrm{l}$ of water). Basal readings were measured using the microplate fluorimeter controlled by an AG-9600 AmpliSensor Minilyzer (sensitivity setting 5, Biotronics Corp.) after a first cycle of $92^{\circ} \mathrm{C}$ for 40 $\mathrm{sec}, 60^{\circ} \mathrm{C}$ for $40 \mathrm{sec}$, and $75^{\circ} \mathrm{C}$ for $40 \mathrm{sec}$. The readings were then recorded after additional cycles to measure the fluorescence decrement, which is a direct function of PCR. Fluorescence readings were analyzed using ASAP software (Biotronics Corp.), which records the fluorescent reading at any given number of cycles by digital numbers (raw reading). The reading after any number of PCR cycles is then compared with the basal reading. A $20 \%$ decrement (index of 0.2 ) of the reading in each of duplicate samples was taken to represent positive amplification.

\section{Southern Blotting}

Following electrophoresis through a 3\% agarose gel, the samples were transferred by the method of Southern (1975). The probes for Southern blotting were prepared by isolation of a PCR product corresponding to a correctly sized gene fragment from the cDNA library in which the gene was known to be transcribed. The PCR product from the appropriate library was purified using the Wizard PCR preparation system (Promega, Madison, WI). The purified PCR product was radiolableled with ${ }^{32} \mathrm{P}$-dCTP using the Rediprime DNA labeling system (Amersham, Arlington Heights, IL). The primer sequences were a gift of Dr. D. Cupo (Gruber et al. 1995). The relevant adult cDNA libraries (Clontech, Palo Alto, CA) from Northern-positive tissues were: apolipoprotein $C$ : liver (HL3006b); platelet receptor: keratinocyte (HL1045b); myelin: hypothalamus (HL1172b); cardiac troponin T: heart (HL1038b); surfactant $D$ : lung (HL3004). Hybridization and filter washing were performed according to Amershams recommendations.

\section{Acknowledgments}

This work was supported by National Institutes of Health grants 1 R01 HL50025 and 1 R01 HG00923, by the American Heart Association and by the Howard Hughes Medical Institute. D.M.K. is an Investigator, W.-J.S. is an Associate and M.V.K. is a Research Specialist, Howard Hughes Medical Institute. Supported by the University of Michigan Cancer Center and Arthritis Center.

The publication costs of this article were defrayed in part by payment of page charges. This article must therefore be hereby marked "advertisement" in accordance with 18 USC section 1734 solely to indicate this fact.

\section{REFERENCES}

Botstein, D., R.L. White, M. Skolnick, and R.W. Davis. 1980. Construction of genetic linkage map in man using restriction fragment length polymorphisms. Am. J. Hum. Genet. 32: 314-331.

Buraczynska, M.J., M.L. Van Keuren, K.M. Buraczynska, Y.S. Chang, E. Crombez, and D.M. Kurnit. 1995. Construction of human embryonic cDNA libraries: HD, PKD1 and BRCA1 are transcribed widely during embryogenesis. Cytogenet. Cell Genet. 71: 197-202.

Casey, G., M. Lo-Hsueh, M.E. Lopez, B. Vogelstein, and E.J. Stanbridge. 1991. Growth suppression of human breast cancer cells by the introduction of a wild-type p53 gene. Oncogene 6: 1791-1797.

Chiang, P.W., G. Dzida, J. Grumet, J.F. Cheng, W.J. Song, E. Crombez, M.L. Van Keuren, and D.M. Kurnit. 1995. Expressed sequence tags from the long arm of human chromosome 21. Genomics 29: 383-389.

Chiang, P.-W., S.-Q. Wang, P. Smithivas, W.-J. Song, E. 


\section{CHIANG EI AL.}

Crombez, A. Akhtar, R. Im, J. Greenfield, S.

Ramamoorthy, M. Van Keuren, C.C. Blackburn, C.-H. Tsai, and D.M. Kurnit. 1996a. Isolation and characterization of the human and mouse homologues (SUPT4H and Supt4h) of the yeast SPT4 gene. Genomics 34: 368-375.

Chiang, P.-W., S.-Q. Wang, P. Smithivas, W.-J. Song, S. Ramamoorthy, J. Hillman, S. Puett, M. Van Keuren, E. Crombez, A. Kumar, T.W. Glover, D.E. Miller, C.-H. Tsai, C.C. Blackburn, X.-N. Chen, Z. Sun, J.-F. Cheng, J.R. Korenberg, and D.M. Kurnit. 1996b. Identification and analysis of the human and murine putative chromatin structure regulator SUPT6H and Supt6h. Genomics 34: 328-333.

Daumer-Haas, C., S. Schuffenhauer, J. Walther, R. Schipper, T. Porstmann, and J. Korenberg. 1994. Tetrasomy 21 pter-q22.1 and Down syndrome: Molecular definition of the region. Am. J. Med. Genet. 53: $359-365$.

Driscoll, D.A., M.L. Budarf, and B.S. Emanuel. 1992. A genetic etiology for DiGeorge syndrome: consistent deletions and microdeletions of 22q11. Am. J. Hum. Genet. 50: 924-933.

Dyck, P.J., P.F. Chance, R.V. Lebo, and J.A. Carney. 1993. Hereditary motor and sensory neuropathies. In Peripheral neuropathy, 3rd ed. (ed. P.J. Dyck, P.J. Thomas, J.W. Griffin, P.A. Low, and J.F. Poduslo), Vol. 2, pp. 1094-1136. W.B. Saunders, Philadelphia, PA.

Gruber, C.E., D. Polayes, M.C. Noon, P. Nisson, W.B. Li, J. Jesse, L. Best, and P.J. Dillon. 1995. Construction of SuperScript human cDNA libraries. BRL Focus 17: 43-44.

Holt, J.T., M.E. Thompson, C. Szabo, C. Robinson-Benion, C.L. Arteaga, M.-C. King, and R.A. Jensen. 1996. Growth retardation and tumor inihibition by BRCA1. Nature Genet. 12: 298-302.

Inoue, K., H. Osaka, N. Sugiyama, C. Kawanishi, H. Onishi, A. Nezu, K. Kimura, S. Kimura, Y. Yamada, and K. Kosaka. 1996. A duplicated PLP gene causing Pelizaeus-Merzbacher disease detected by comparative multiplex PCR. Am. J. Hum. Genet 59: 32-39.

Kan, Y.W. (1980-81) Hemoglobin abnormalities: molecular and evolutionary studies. Harvey Lect. 76: 75-93.

Kurnit, D.M., J.-F. Cheng, Y. Zhu, M.L. Van Keuren, Y. Jiang, Y.Z. Pan, K. Whitley, and E. Crombez. 1995. Transcription patterns of sequences on human chromosome 21. Cytogenet. Cell Genet. 71: 203-206.

Lashkari, D.A., S.P. Hunicke-Smith, R.M. Norgren, R.W. Davis, and T. Brennan. 1995. An automated multiplex oligonucleotide synthesizer: Development of high-throughput, low-cost DNA synthesis. Proc. Natl. Acad. Sci. 92: 7912-7915.

Lasko, D., W. Cavenee, and M. Nordenskjold. 1991. Loss of constitutional heterozygosity in human cancer. Annu. Rev. Genet. 25: 281-314.
Mansfield, E.S. and M.N. Kronick. 1993. Alternative labeling techniques for automated fluorescence based analysis of PCR products. BioTechniques 15: 274-279.

Nigro, J.M., S.J. Baker, A.C. Preisinger, J.M. Jessup, R. Hostetter, K. Cleary, S.H. Bigner, N. Davidson, S. Baylin, P. Devilee, T. Glover, F.S. Collins, A. Weston, R. Modali, C.C. Harris, and B. Vogelstein. 1989. Mutations in the p53 gene occur in diverse human tumour types. Nature 342: 705-708.

Reiter, L.T., T. Murakami, T. Koeuth, L. Pentao, R.A. Muzny, R.A. Gibbs, and J.R. Lupski. 1996. A recombination hotspot responsible for two inherited peripheral neuropathies is located near a mariner transposon-like element. Nature Genet. 12: 288-297.

Schena, M., D. Shalon, R.W. Davis, and P.O. Brown. 1995. Quantitative monitoring of gene expression patterns with a complementary DNA microarray. Science 270: $467-470$.

Schneeberger, C., P. Speiser, F. Kury, and R. Zellinger. 1995. Quantitative detection of reverse transcriptase-PCR products by means of a novel and sensitive DNA stain. PCR Methods and Applications 4: 234-238.

Scoggin, F., and D. Patterson. 1982. Downs syndrome as a model disease. Arch. Int. Med. 142: 462-464.

Slamon, D.J., W. Godolphin, L.A. Jones, J.A. Holt, S.G. Wong, D.E. Keith, W.J. Levine, S.G. Stuart, J. Udove, A. Ullrich, and M.M. Press. 1989. Studies of the HER-2/neu proto-oncogene in human breast and ovarian cancer. Science 244: 707-712.

Southern, E.M. 1975. Detection of specific sequences among DNA fragements separated by gel electrophoresis. J. Mol. Biol. 98: 503-517.

Szollosi, J., M. Balazs, B.G. Feuerstein, C.C. Benz, and F.M. Waldman. 1995. ERBB-2 (HER2/neu) gene copy number, p185HER-2 overexpression, and intratumor heterogeneity in human breast cancer. Cancer Res. 55: $5400-5407$.

Van Ommen, G.J., M.H. Breuning, and A.K. Raap. 1995. FISH in genome research and molecular diagnostics. Curr. Opin. Genet. Dev. 5: 304-308.

Velculescu, V.E., L. Zhang, B. Vogelstein, and K.W. Kinzler. 1995. Serial analysis of gene expression. Science 270: $484-487$.

Von Eggeling, F., M. Freytag, R. Fahsold, B. Horsthemke, and U. Claussen. 1993. Rapid detection of trisomy 21 by quantitiative PCR. Hum. Genet. 19: 567-570.

Wang, C.N., K. Wu, and H.-T. Wang. 1995. Quantitative PCR using the AmpliSensor assay. In PCR primer: $A$ laboratory manual (ed. C.W. Dieffenbach and G.S. Dveksler), pp. 193-202. Cold Spring Harbor Laboratory Press, Cold Spring Harbor, NY.

Received April 23, 1996; accepted in revised form August 5, 1996. 


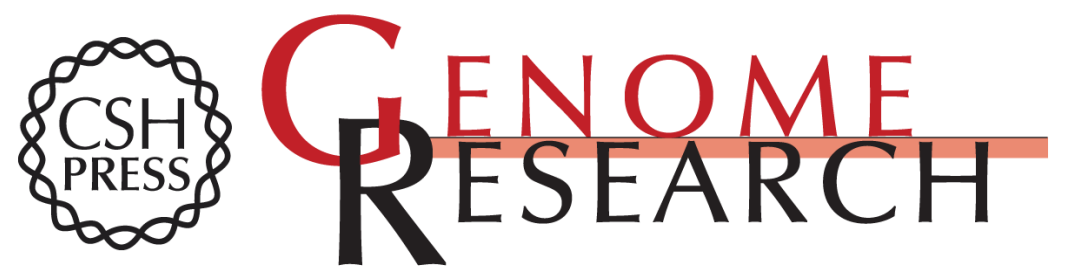

\section{Use of a fluorescent-PCR reaction to detect genomic sequence copy number and transcriptional abundance.}

P W Chiang, W J Song, K Y Wu, et al.

Genome Res. 1996 6: 1013-1026

Access the most recent version at doi:10.1101/gr.6.10.1013

References This article cites 27 articles, 5 of which can be accessed free at:

http://genome.cshlp.org/content/6/10/1013.full.html\#ref-list-1

\section{License}

Email Alerting Receive free email alerts when new articles cite this article - sign up in the box at the Service top right corner of the article or click here.

\section{Affordable, Accurate Sequencing.}

To subscribe to Genome Research go to:

https://genome.cshlp.org/subscriptions 